\title{
Göç, Toplumsal Uyum ve Aidiyet
}

\author{
Mehmet Akif Sözer*
}

Makale Geliş Tarihi: 07.11.2019

Makale Kabul Tarihi: 28.12.2019

DOI: $10.35675 /$ befdergi.643948

Öz

Bireylerin birbirlerine olan ihtiyaçlarından kaynaklanan birlikte yaşama güdüsü; psikoloji, sosyal psikoloji ve sosyoloji alanlarında gerçekleştirilen araştırmalarda ele alınan önemli konulardan birisidir. Özelikle son ylllarda yaşanan yoğun göç ve buna bă̆ll gerçekleşen sosyal değişim ve dönüşümler; uyum ve aidiyet kavramlarının yeniden yorumlanmasına neden olmuş ve bu kavramların pek çok boyutunu tartışmaya açmıştır. Bu bağlamda, aidiyet temel bir insan güdüsü olarak tanımlanmakta, bireyler arası ilişkilerin inşa edilmesinde, geliştirilmesinde ve sürdürülebilir bir hale gelmesinde aidiyetin işlevsel bir istek olduğu vurgulanmaktadır. Göç edenlerin ev sahibi ülkede yaşadıkları en önemli sorunlar: ev sahibi ülke dilini iyi ya da hiç bilmemeleri, istihdam, dilden ve ev sahibi toplumunun verdiğ $i$ tepkiden kaynakl sorunlar yaşamaları, barınma sorunu, ev sahibi toplumla farkl bir dine sahipse dini ritüellerini gerçekleştirememe sorunu, yabancılara karşı olumsuz tutumların şiddeti, yeni çevreye uyum süreci, ekonomik zorluklar ve kültürel farklılıklar şeklinde sıralanabilir. Bu sorunların çözümü için, göçmenlerin kültürleri, dinleri, sosyoekonomik yapıları ve ev sahibi kültüre olası katkıları konusunda öncelikle detaylı bilgilere sahip olunması ile mümkündür. Gö̧̧menlerin detaylı bilgileriyle tanınmalarının ardından onlara yönelik ekonomik, sosyal ve kültürel politikalar belirlenebilir. Böylece, ev sahibi topluma da katkı yapmaları săglanabilir.

Anahtar Kelimeler: Aidiyet, göç, kimlik, toplumsal uyum

\section{Migration, Social Adaptation and Belonging}

\begin{abstract}
The motivation to live together because of the need of the individuals to each other is one of the most important issues that become a topic of research in psychology, social psychology and sociology. In particular, the intensive immigration experienced in recent years and the social changes and transformations that take place in relation to this have led to reinterpretation of concepts of cohesion and belonging, and opened up many of their dimensions to discussion. Belonging is defined as a fundamental human urge and is functional desire to build, develop and sustain inter-individual relations. The most important problems that migrants live in host countries are: they do not know the language of the host country well; reactionary problems of host society, language problems and legal status problems in accessing employment; payability and the problem of housing in terms of the host society; the problem of failing to fulfill religious rituals when migrants are in different
\end{abstract}

*Gazi Üniversitesi, Gazi Eğitim Fakültesi, Temel eğitim Bölümü, Ankara, Türkiye, akif@gazi.edu.tr, ORCID ID: 0000-0002-1291-4067

Kaynak Gösterme: Sözer, M.A. (2019). Göç, toplumsal uyum ve aidiyet. Bayburt Eğitim Fakültesi Dergisi, 14(28), 418-431. https://doi.org/10.35675/befdergi.643948 
religion; the proportion of foreigners in comparison to the national population in the migrated country and the violence of attitudes towards foreigners, the process of adjustment to the new environment, economic difficulties and cultural differences. Related persons and institutions with the issue should have detailed information on the cultures, religions and socioeconomic structures of the migrants living in the region, and their possible contribution to the host countries' cultural heritage. After getting informed about the immigrants in detail, economic, social and cultural initiative fields can be identified for them. Therefore, immigrants may support the host country in such areas as special field services etc.

Keywords: Belonging, migration, udentity, social adaptation

\section{Giriş}

Bireylerin başkalarına olan ihtiyaçlarından kaynaklanan birlikte yaşama güdüsü; psikoloji, sosyal psikoloji ve sosyoloji alanlarında gerçekleştirilen araştırmalarda ele alınan önemli konulardan biridir. "Birlikte yaşamak", ifadesi ise bireylerin diğerleriyle kurduğu sosyal ilişkilerinin sürekliliği ifade etmek anlamında kullanılmaktadır. Bu süreklilik bireylerin birbirlerine olan bağlılıklarının kaçınılmaz nedenidir. Bununla birlikte bireylerin birlikte yaşamasını mümkün kılan ve düzenleyen birtakım normların ve değerlerin birey tarafindan öğrenilmesi ise toplumsallaşma süreci içerisinde gerçekleşir. $\mathrm{Bu}$ durum, ilk insandan günümüze kadar bireyin temel ihtiyaçlarından olan uyum ve aidiyet konusunun ele alınmasında sadece psikolojik değil sosyolojik bir yaklaşımı da gerektirmektedir (Alptekin, 2011: 60) . Özellikle son dönemde yaşanan yoğun göç ve buna bağlı gerçekleşen sosyal değişim ve dönüşümler; uyum ve aidiyet kavramlarının yeniden yorumlanmasına katkı getirmiş ve pek çok boyutunu tartı̧̧maya açmıştır. Ancak, kimi zaman uyum kavramı "zorunlu kültürel asimilasyonist bir süreç" olarak ele alınabilmekte ya da uyumun sadece ekonomik boyutuna odaklanıp sosyokültürel boyutu gözardı edilebilmektedir. Ayrıca gerek uyum gerekse aidiyet kavramlarının taşıdığı belirsizlikler, bu konuda nitelikli veri toplanmasının zorluğu, olumsuz bazı bakış açıları, kamu politikalarının oluşturulmasında yaşanan güçlükler, yoğun ve baskın genellemelere gidilmesi, söz konusu kavramlar kapsamında uzlaşı kültürünün oluşturulamayıp tek bir perspektifle ele alınması bu kavramların tartışılmasını önemli hale getirmiştir. Bu bakış açısıyla araştırma kapsamında göç ve kimlik oluşumu kavramları ekseninde aidiyet ve uyum kavramları tartışılmıştır.

\section{Aidiyet}

Aidiyet kavramı sözcük anlamı olarak ilişkinlik, ilgi (TDK,2018); mensubiyet, ait olma hali (Alptekin, 2011) anlamlarında kullanılmaktadır. Aidiyet temel bir insan güdüsü olarak tanımlanmakta bireyler arası ilişkilerin inşa edilmesinde, geliştirilmesinde ve sürdürülebilir bir hale gelmesinde ise işlevsel bir istek olduğu belirtilmektedir (Baumeister ve Leary,1995). Ancak kavramsal olarak aidiyet birey ve toplum arasındaki durağan ve organik bir ait olma hali olarak algılanmamalıdır. Tellefsen ve Thomas (2005: 24) aidiyeti, "değer verilen bir ilişkiyi, uzun süreli sürdürme isteği” olarak tanımlamaktadır. Aidiyet kavramı bireyin kendini nasıl konumlandırdığına ve anlamlandırdığına bağlı olarak insana, nesneye, mekâna, komşuluk ilişkilerine, kültüre, siyasete, çeşitli sosyal tabakalara, etnik kökene dayalı olarak da 
inşa edilebilen akışkan bir kavram olarak nitelendirilmelidir. Bu kapsamda aidiyet bireylere kimi zaman benzer çatılar altında buluşmayı sağlarken, kimi zamanda neredeyse bir turnusol kâğıdı görevi yaparak bizi “öteki”lerden ayırabilmektedir. Kaldı ki aidiyet kapsamında bireyin kimliği inşa edilirken "Ben kimim?" sorusu kadar "Ben kim değilim?" sorusu da önem arz etmektedir. Bu, oluşturulan öteki kurgusunu da destekler. Öte yandan aidiyet bir eklemlenme, çıkarılma veya bütünleşmeye yönelik bir zaman dilimi olarak da tanımlanabilmektedir (Koçak, 2011). Bu doğrultuda aidiyet kavramı çok geniş bir perspektifle ele alınabilir. Alan yazın incelendiğinde yetişkinler arası ilişkiler (Hazan ve Shaver, 1994), sosyal ilişkiler (Weiss, 1988), çok kültürlülük (K1lıçoğlu,2014), kentsel dönüşüm (Deringöz, 2017), yerel mutfaklar (Bezirgan ve Koç,2014), örgütsel vatandaşlık (Akdoğan ve Köksal, 2014), tüketici davranışları (Kadığlu,2013) vb. konularda aidiyet kavramının ele alındığı görülebilmektedir.

Aidiyet kavramıyla ilişkili olarak Baumeister ve Leary (1995) tarafından gerçekleştirilen "The Need to Belong: Desire for Interpersonal Attachments as a Fundamental Human Motivation" adlı çalışmada temel bir insan güdüsü olarak nitelendirilen aidiyet kavramı, bireylerarası ilişkilerin inşa edilmesinde, sürdürülebilir hale getirilmesinde ve zenginleştirilmesinde işlevsel ve evrensel bir istek olarak ele alınmaktadır. Aidiyetin alt boyutları incelendiğinde ise "bağlılık" ve "kimlik" kavramlarının ön plana çıktığı görülmektedir.

\begin{tabular}{|c|c|}
\hline Alan veya mekânsal kimlik & $\begin{array}{l}\text { - Kişisel kimlik teorisine göre üç boyut } \\
\text { bulunmaktadır. Bu boyutlar; bilişsel ve } \\
\text { tanımlayıcı boyut, duygusal boyut ve } \\
\text { gereksinim boyutlardır. } \\
\text { - Alan veya mekânsal kimlik kavramının } \\
\text { fonksiyonları dört adettir. Bunlar; tanımlama, } \\
\text { anlamlı gereksinme, anlamlandırma ve } \\
\text { bağdaştırıcı değişimlerdir. Alan veya } \\
\text { mekânsal kimlik bağlılıktan etkilenmektedir } \\
\text { ve daha yüksek aidiyete neden olmaktadır. }\end{array}$ \\
\hline Alan veya mekânsal bağlılık & $\begin{array}{l}\text { - Alan veya mekânsal bağlılık bir alan veya } \\
\text { mekâna verilen özel değerdir. } \\
\text { - Alan veya mekâna verilen özel değer farklı } \\
\text { alan veya mekânlara verilen değer ile } \\
\text { karşılaştırılarak oluşur. } \\
\text { - Alan veya mekânsal bağlılık zamanla ve } \\
\text { deneyimlerle artar }\end{array}$ \\
\hline Duygusal bağlılık & $\begin{array}{l}\text { - Duygusal bağ fiziksel unsurlara karşı oluşan } \\
\text { hislerdir. } \\
\text { - Duygusal bağ boyutu daha fazla } \\
\text { araştırılması gereken bir boyuttur. }\end{array}$ \\
\hline Sosyal bağlilık & - Sosyal bağlılık herhangi bir alan veya \\
\hline
\end{tabular}


mekânda gerçekleşen sosyal etkileşimler

sonucunda meydana gelir.

Kaynak: Brocato, 2006:27-28; Aktaran Bezirgan, 2014:58.

Aidiyet kavramı bağlılık açısından duygusal ve mekânsal boyutta bireyin nereye, neye, nasıl ait olduğunu tanımlarken bir yandan da bireyin hangi duygulardan, inançlardan, siyasi yönelimlerden, kim olduğundan da etkilenmektedir. Bireyin doğumu aracılığıyla bir aileye, bir topluluğa, bir toplumsal düzene mensubiyeti başlamakta ve böylelikle kök salmaya başlayan aidiyet kavramı; ilerleyen süreçlerde hem bir zorunluluk hem de bir tercih olarak nitelendirilebilecek konuma gelmektedir. Bireysel temelde değerlendirildiğinde deneyim, kültür, hazırbulunuşluk, inanç, bakış açısı, mekân, nesne gibi unsurlar aidiyet kavramının iskeletini oluşturduğu için söz konusu kavrama ilişkin ortak bir tanımlama ya da genelleme mümkün görünmemektedir. Son dönemde ise daha çok sosyolojik açıdan kimlik-aidiyetuyum kavramlarının göç ekseninde tartışıldığı görülmektedir.

Özelikle göçmenler açısından düşünüldüğünde aidiyet kavramının kimlik boyutunun ön plana çıktığı, kimlik oluşumunun kritik öneme sahip olduğu görülebilir. "Kimlik hem bireyin kendisi ile diğeri arasında bir farklılaşma içerir, hem de kendisiyle diğerleri arasındaki özdeşleşmelerden hareketle inşa edilir" (Bilgin, 2007:95). Göçmenler zaman içerisinde belirli bir oranda uyum sağlarken aidiyet ve kimliklerini tanımlama konusunda belirli sıkıntılar yaşamaktadır. Çünkü kimlik ve aidiyet kavramları sadece geçmişten gelen mutlak ve değişmez öğelerle beslenmez, geleceğe yönelik bir takım hedeflerle birlikte içerisinde bulunulan kültürel etkileşimle birlikte inşa edilir. Yıldız (2007: 16)'ın belirttiği üzere "kimlik, sahip olduğu içeriğin sağlamlığına, güçlülüğüne ve belirginliğine göre kişilerin toplum içinde bireysel olarak veya farklı toplumlarla olan ilişkilerinde yönlendirici veya kısıtlayıcı bir içerik kazanabilmektedir. Bu boyutu ile kimlik, toplumsal bütünleşme süreçlerinde baskın bir kavram olarak karşımıza çıkmaktadır”. Çoğu zaman yeni karşılaştı̆̆1 toplumda toplumsal bir kimliğe sahip olamayan göçmenler parçalanmış kimlikler üzerinden çok sayıda bireysel ve toplumsal soruna neden olmaktadır. Bu süreçler de çoğu zaman köklerinden kopmadan yeni geldiği toplumda kimliğini inşa eden bireyler değil, dışarıdan kimliği giydirilmiş ${ }^{1}$; kabul edilme-reddedilme çizgileri ve kültürel katılık arasında sıkışan göçmen kimliklerini meydana getirmektedir. Akıncı, Nergiz ve Gedik (2015: 76)'in belirttiği üzere "farklı kültür ve etnik yapılardan göç edenlerin kendi özlerine ait kimlik arayışları karmaşık bir hâl aldığında göç ettikleri toplumdaki insanlara olan sosyal bütünleşmeleri yerine çatışma yaşamaları kendi kimliklerini kabul ettirme savaşına doğru olumsuz bir süreci doğurma tehlikesi de yaratabilmektedir".

Bireyin birçok kimliğe sahip olmasının yanı sıra günümüzde toplumsallığın sınırlarının genişlemesi, kimlik algılarının çoğalmasına ve farklılaşmasına neden olmuştur. Özellikle bireysel ve kolektif kimlikler göz önünde bulundurulduğunda bütünün bir parçası olarak

\footnotetext{
${ }^{1}$ Aşkın (2007: 216)'ın ifade ettiği üzere “İnsan, içinde yaşadığı toplumun milli, dini, siyasal, ekonomik değer yargılarının bir ürünü olmaya yönlendirilmektedir. Yani toplumsal üretim araçları, belli kimliklere sahip insanlar üretmektedir. İşte bunlar 'giydirilmiş kimliklerdir'”.
} 
kolektif kimlikler dayanıklılığını korurken; postmodern zamanının bir öncülü olarak bireysel kimlikler esnek, kırılgan ve sürekli yeniden yapılanmaktadır (Özdil, 2017). Postmodern anlayışın bir gereği olarak idealize edilmiş bir bakış açısından uzaklaşılarak üst bir kimliğe karş1 koyan bir anlayış oluşmuş kimliklerin yerelliği, farklılığ1 ve heterojenliği kabul görmeye başlamıştır (Dalbay, 2018). Diğer bir deyişle genişleyen ve karmaşıklaşan toplumsal kategorilerde bir taraftan bireylerin içerden kendilerine ve çevrelerine yükledikleri kimlikler değişmekte, diğer taraftan da aidiyet kategorileri çoğalmaktadır. Kimliğin bir "sorun" halini alışı ise diğer insanlarla kurulan etkileşimlerin yoğunlaşmasına paralel olarak, bu çeşitlenmeye dışarıdan yapılan yüklemelerin eklemlenmesiyle gerçekleşir. Bu aşamada kimlik daha dinamik ve organik, aynı zamanda "tanınma, tanıma" ve aidiyet olmak üzere çift bileşenli bir yapıya bürünür (Bozkurt, 2006). Bu bağlamda kimliğin, kültürle yoğrulan bir aidiyet olduğu gerçeği ise gözden kaçırılmamalıdır.

\section{Uyum}

Uyum, kişinin sahip olduğu bireysel özellikleri taşıyarak kendi benliği ve çevresi ile kurduğu dengeli ilişki sürecine denir (Avc1, 2006). Uyum kavramıla, genellikle bir durumdan diğerine geçme ifade edilmek istenmektedir. Uyum kavramı konusunda Philip'in tanımı üzerinde genel bir görüş birliği vardır. Bu tanıma göre uyum bireyin yerel gelenek ve adetlere uyum sağlamak için davranışlarını değiştirmesidir (Murphy-Lejeune, 2001). Uyum süreci, hayata sağlıklı bir şekilde devam edebilmek, farkına varılan kişisel özellikleri doğru yerde ve doğru şekilde ortaya çıkarmak ve ihtiyaç duyulan farklı özellikleri edinmek ya da geliştirmek için çok önemli bir fursattır (Gençöz, 1998).

Birçok çalışma ve araştırmada uyum ve aidiyet, daha çok "toplumsal bütünleşme" ve "entegrasyon" kavramları ile birlikte ele alınmaktadır. Türkiye Büyük Millet Meclisi İnsan Haklarını İnceleme Komisyonu Mülteci Hakları Alt Komisyonu Göç ve Uyum Raporu (2018)'nda belirtildiği üzere bu kapsamda kavramsal bazda çok kültürlülük, empati, tolerans, kaynaşma, katılım, birlikte var olma, asimilasyon, kabullenme, absorbe etme, bütünleşme, entegrasyon, uyum... gibi pek çok sayıda kavram tartışılmaktadır². Bu süreçte göçmenler asimilasyon sürecinden farklı olarak hibritizasyon süreci ile birlikte kendilerine eşsiz bir kimlik inşa etme firsatı da bulabilirler. Bu durumun bir neticesi olarak Çağırkan (2016)'ın da ifade ettiği gibi “Amerikalı Çinli, Türk asıllı Alman Futbolcu, Punkçı, Arsenal Taraftarı, vb." kimlik tanımlamaları yapılabilmektedir. Hibrit kimlik oluşturma süreci uyum sürecini tamamlayan göçmenler için en sıkıntılı ve sancılı süreçlerden biri olan "kendini tanımlama" basamağı açısından da önem taşımaktadır. Çünkü kişilere kimlik açısından kendine has özgür bölgeler oluşturma firsatı yaratmaktadır.

İster toplumsal bütünleşme ister entegresyon ya da uyum kapsamında değerlendirilebilecek çok sayıda kavram ele alındığında önemli olan hususlardan biri bireyin kendi niteliklerinden vazgeçmemesidir. Toplumsal bağlamda ise, bütünleşme diye

\footnotetext{
${ }^{2}$ Yabancılar ve Uluslararası Koruma Kanunu'nun 96. Maddesinde ise "uyum” kavramı kullanılmış, öngörülen uyumun; ne asimilasyon ne de entegrasyon olduğu vurgulanmış "göçmenle toplumun gönüllülük temelinde birbirlerini anlamalarıyla ortaya çıkan harmonizasyon" açıklamasına yer verilmiştir (http://www.goc.gov.tr/icerik3/uyum-hakkinda $409564 \quad 566$ )
} 
adlandırılan olgu, çevresiyle arasındaki kesin sınırları bulunan bir toplumsal sistem içinde yer alan istikrarlı ve işbirliğine dayalı ilişkiler bütünüdür" (Şirin, 2012:401). Bütünleşme bu aşamada sadece sosyo-kültürel kapsamda değil, daha geniş bir perspektifle ele alınmalıdır. Şeker (2015)'in ifade ettiği üzere "farklı göçmen grupların uyumu konusunda yapılandüzenlemeler; öncelikli olarak hukuki, ekonomik, uluslararası beklentiler gibi farklı bakış açılarını ve beklenti düzeylerini yansıtmakta, yazılı olarak ifade edilmelerine rağmen gerçek hayatta bu grupların beklentilerinin, ihtiyaçlarının karşılanması ve baskın toplumun beklentilerinin karşılanması konularında bazı eksiklikler ve aksaklıklar bulundurdukları da bir gerçektir”. Göçmenler açısından ev sahibi ile birlikte barınma, sağlık, istihdam, eğitim gibi alanlarda bir bütünleşme sağlanamadıkça; içe kapanma, kendi sahip olduklarını daha şiddetle savunur hale gelme, "öteki”ne karşı sürekli tetikte olma, önyarg1 ve kalıp yargılar oluşturma gibi olumsuz sonuçlar ortaya çıkarabilmektedir.. Bu bağlamda toplumsal bütünleşmenin kaynağının sadece "yeni gelenler” değil, aynı zamanda "ev sahibi” olduğu unutulmamalıdır.

\section{Göç, Uyum ve Aidiyet}

Uyum ve aidiyet kavramlarının özelikle son dönemde uluslararası arenada yaşanan hızlı değişim ve dönüşümlerin bir sonucu olarak; sosyolojik bağlamda "göç" kavramı ile birlikte tartışılmasının hız kazandığı görülmektedir. Ancak son yüzyılda göç kavramı yeni kavramsal kategoriler 1şığında da değerlendirilebilmektedir. Özbek ve Şahan (2016: 160)'ın belirttiği üzere "İklime bağlı göçler, sağlık göçleri, yaşlı göçleri (elderly migration), emekli göçleri (retirement migration) ve bunların hepsini kapsayan bir şekilde ortaya çıkan yaşam biçimi göçleri (life-style migration) kategorileri anlam kazanmaktadır”. Gerek göç kavramına ilişkin oluşturulan bu türden bir kavramsal kategorilendirme, gerekse iç ve dış göç olarak yapılan genel sınıflama biçimi dikkate alındığında; göçün gerekçesi, göçün farklı alanlardaki bütünleşik etkileri, göçmen davranış ve tutumları, göç edilen bölgedeki yerleşik kesimin göçmenlere karşı tepkileri vb. hususlar her ne olursa olsun uyum ve aidiyet konusu tüm bireyleri kapsamaktadır. Söz gelimi Türkiye'de köyden şehre yaşanan bir iç göç dalgası ya da Libya'dan Avrupa birliği ülkelerine yaşanan diş göç süreci göz önünde bulundurulduğunda yerleşik bir düzene tüm "yeni gelen"ler için uyum ve aidiyet öncelikli kavramlar arasındadır. Türkiye de açık kapı sınır politikası ve insani bir iltica anlayışını yüzyıllardır sürdürülmesi, İslam dininin ihtiyaç sahibi bireylere bakış açısı, Anadolu topraklarının hoşgörü ile yoğurulması nedeniyle yoğun biçimde göç alan ülkelerin başında gelmektedir ${ }^{3}$. Türkiye'nin Cumhuriyet tarihinden öncesi ve sonrasında yoğun göç akımlarına sahne olmasının birçok nedeni bulunmaktadır. Bunlar sırasıyla; bulunduğu stratejik konumu, günümüz için en önemli etkenlerden biri olarak sayılabilen Avrupa Birliği (AB) ülkelerine yönelen göç için $A B$ 'nin dış sınırlarına ulaşmaya için en uygun görülen güzergâh üzerinde olması, komşu ülkelerindeki savaş, iç savaş ve siyasi, ekonomik her türlü istikrarsızlık ortamları ve bu ortamların sürekliliği, sınır bölgelerindeki akrabalık ilişkilerinin varlığı ve doğu ile güneydoğu

\footnotetext{
${ }^{3}$ Türkiye Büyük Millet Meclisi İnsan Haklarını İnceleme Komisyonu Mülteci Hakları Alt Komisyonu Göç ve Uyum Raporu (2018)'na göre Türkiye'de bu gün 3,4 milyonu geçici koruma statüsüyle, 300 bini uluslararası koruma başvurusuyla, 600 bini ikamet izniyle olmak üzere yaklaşık 190 farklı ülkeden, farklı statülerde 4,3 milyon göçmen yaşamaktadır (https://www.tbmm.gov.tr/komisyon/insanhaklari/docs/2018/goc ve uyum raporu.pdf)
} 
sınırlarının coğrafi yapısı itibariyle göç kontrolünün güçlüğü (göçmenlerin kolaylıkla sınırları aşılabilmesi) şeklinde sıralanabilir.

2011 yılından bu yana, Suriye'de yaşanan iç savaş ve sıkıntılar ile şimdiye kadar karşılaşılmayan bir boyutta göç akımıyla karşı karşıya kalınmıştır. Açık kapı sınır politikası ile sınır/komşu ülkede yaşanan bu drama acil ve insani bir tavır sergilenmiştir. Bu insanlar önce sınır bölgelerinde geçici kamplar kurularak buralara yerleştirilmiş ancak bu kamp alanlarının kapasitesinin yetersizliği ve ülkelerindeki çatışmalar devam edince yeni gelen göç akımlarıyla beraber, göçmenlerin bir kısmı Türkiye'de farklı şehirlerde kendi başlarının çaresine bakmak durumunda kalmışlardır (Çakırer; Özservet, 2014). İçişleri Bakanlığı Göç İdaresi Genel Müdürlüğü'nü 22 Mart 2018 tarihli verilere göre, Türkiye'deki biyometrik verileriyle kayıt altına alınan Suriyeli mülteci sayısının bir önceki aya göre 21 bin 59 kişi artarak toplam 3 milyon 561 bin 707 kişi olduğunu belirtmiştir. Bu kişilerin 1 milyon 931 bin 717'si erkeklerden, 1 milyon 629 bin 990'1 ise kadınlardan oluşmaktadır (https://www.umhd.org.tr/ 2018/ 04/ turkiyedeki - suriyeli-multeci-sayisi-20-bin-artti/). Hemen hemen hiçbir ülkede, tarih boyunca bu kadar kısa sürede bu kadar çok sığınmacıyla/göçmenle karşılaşma durumu yaşanmamıştır.

Göç olgusuna ilişkin son dönem alanyazın incelendiğinde söz konusu olgu artık "kriz, ekonomik harcama, suç oranında artış, yabancılar sorunu vb." olumsuz etiketlerle ya da sadece STK'ların, akademisyenlerin veya hükümetlerin "baş etmesi gereken" yıkıcı bir kavram olarak ele alınmamaktadır. Uyum ve aidiyet kavramları ile birlikte göç olgusu "kültürel katma değer ve firsatlar yaratması, kamu düzeninin güçlendirmesi, toplumsal zenginlik, yeni bir toplumsallaşma süreci vb.” kavramlarla birlikte tartışılmaktadır. Bu kapsamda uyum ve aidiyet sadece göçmenlerin ekonomik ihtiyaçlarının karşılanması, sağlık ya da barınma gereksinimlerinin giderilmesi olarak algılanmamalı, bunlarla birlikte sosyal, eğitsel ve kültürel süreçlerde de niteliğin sağlanması olarak kabul görmelidir. Uyum sürecinde hukuksal anlamda sağlanan eşitlik eylemsel eşitliğe de dönüştürülerek "içeriden biri olma" anlayışıyla aidiyet duygusu oluşturulmalıdır. Ancak unutulmamalıdır ki aidiyet ve uyum süreçleri, kabul ve saygı görme gibi toplumsal açıdan sancılı dönemleri de içermektedir. 2014 yılında Hacettepe Üniversitesi Göç ve Siyaset Araştırmaları Merkezi tarafından gerçekleştirilen Türkiye'deki Suriyeliler: Toplumsal Kabul ve Uyum adlı araştırmada Türkiye'deki Suriyeliler konusunda, Türk toplumunun kabul düzeyinin son derece yüksek olduğu, ancak sınırlarının da kendisini belli ettiğini, özellikle de kamu hizmetlerinde aksamalar, iş kaybetme kaygıları ve doğrudan Suriyelilerden kaynaklanacak güvenlik kaygılarının; "misafirperverliğin" nefrete, düşmanlığa dönüşmesi potansiyelinin ciddiye alınması gerekliliği, toplumsal kabulün sürdürülebilir olmasının ancak kapsamlı bir göç yönetimi ile söz konusu olabileceği öngörüsünde bulunulmaktadır.

İki kültürün karşılaşması sırasında yaşanan farklı deneyimler, ülke içi ve uluslararası göç sürecinin her ikisinde de karşılaşılabilmektedir. Bir göçmen başka bir kültürde çok uzun yıllar yaşasa bile kendi kimliğinde ve kültüründe asla değişmeyen veya yeni bir kültürle etkileşime geçildiğinde çok kısa bir süre içerisinde değişebilen öğeleri olabilmektedir. 
Göç edenlerin ev sahibi ülkede yaşadıkları en önemli sorunlar: geldikleri ülkenin dilini iyi ya da hiç bilmemeleri, istihdam, dilden ve ev sahibi toplumunun verdiği tepkiden kaynaklı sorunlar, barınma sorunu, ev sahibi toplumla farklı bir dine sahip olması durumunda dini ritüellerini gerçekleştirememe sorunu, göç edilen ülkedekilerin yabancilara karşı olumsuz tutumları, yeni çevreye uyum süreci, ekonomik zorluklar ve kültürel farklılıklar şeklinde sıralanabilir (Çakırer Özservet, 2016: 54). Bu noktada, konuyla ilgili kişi ve kuruluşların, bölgesinde yaşayan göçmenlerin, kültürleri, dinleri ve sosyoekonomik yapıları ve ev sahibi kültüre olası katkıları konusunda detaylı bilgilere sahip olmaları büyük önem taşımaktadır. Göçmenlerin ayrıntılı bir şekilde tanınmalarının ardından onlara yönelik ekonomik, sosyal, kültürel politikalar daha sağlıklı bir şekilde belirlenebilir. Böylece hem ev sahibi topluma uyumları ve hem de göç ettikleri ülkeye katkı sağlamalarına destek olunabilir.

\section{Değerlendirme}

Kuşkusuz göçten en fazla etkilenenlerin başında çocuklar gelmektedir. Kaştan (2015) göç deneyimi geçirmiş bir çocuğun temel problemlerini dil, ekonomik sorunlar, çocuğun çalıştırılmak zorunda bırakılması dolayısıyla ortaya çıkan problemler ve ailede çocuk sayısının fazlalaşmasından kaynaklı sorunlar olarak ele almıştır. SETA ve Theirworld (2017) tarafından gerçekleştirilen araştırmada ise Suriyeli öğrencilerle ilgili olarak temel sorunların finansman, planlama ve yönetim, eğitim öğretim ve okula uyum kapsamlarında değerlendirildiği görülmektedir. Bu doğrultuda okula uyum kapsamında öğretmenler ve okul yönetimi ile ilişkiler, Türkçe öğrenimi, karma eğitime uyum, veli tutumu belirleyici faktörler olarak tespit edilmiştir. Suriyeli öğrencilerin eğitim gereksinimlerinin giderilmesinin; yeni bir ülkeye, sosyal hayata ve onun kurallarına, yeni bir yurttaşlığa hazır olma ve bütünleşme manası ile değerlendirilebileceği ifade edilmiştir (Gencer,2017 s: 840).

Toplumsal uyum ve aidiyet konusu da çocuklar açısından ele alındığında eğitim kurumlarına büyük sorumluluk düşmektedir. Öncelikli olarak, eğitim kurumlarında, farklı bir kültür ve aile ortamından gelen bu çocuklara karşı duyarlı olunmalıdır. Çocukların hem akademik başarılarını hem de sosyal uyumları etkileyen en önemli faktörlerden biri olan dil sorunu öncelikli olarak çözülmelidir. Özellikle ergenlikle beraber yaşanan uyum ve kimlik karmaşası süreci göçmen çocuğun yabancı bir dili öğrenmeye ilişkin direnç göstermesine, devamsızlığa, akademik başarısızlığa ve disiplinsizliğe neden olabilmektedir ${ }^{4}$. Dil öğrenme sürecinde bu durum göz önünde bulundurulmalıdır.

Uyum sürecinde dil konusu sadece öğrenci ya da öğretmenler açısından tek boyutlu olarak değil, anne-babalar açısından da değerlendirilmeli; dilin bir bariyer olarak görülmesinin veya anadilin unutulması endişelerinin giderilmesi gerekmektedir. Bu bağlamda, anne-babaların da Türkçe öğrenmesi teşvik edilmelidir. Ebeveynlerin dil öğrenimi konusunda, ülkeye ve ülke

\footnotetext{
${ }^{4}$ OECD, dili göçmen çocukların entegrasyonu sürecinde en önemli engellerden biri olarak ifade etmektedir. Birinci kuşak göçmen çocukların yüzde 64'ü ve ikinci kuşağın yüzde 41'i evde ve okulda eğitim aldıkları dilden başka bir dilde konuştuğu; dolayısıyla PISA 2012 sonuçlarına göre göçmen çocukların özellikle okuma testlerinde daha düşük bir performans gösterdiği ifade edilmektedir (http://www.hurriyet.com.tr/egitim/oecd-gocmen-ogrencileri-kaybetmeyin-40028610).
} 
kültürüne uyumu amaçlanarak, ilgili kurumlar tarafından eğitimler verilmelidir. Özellikle ev sahibi ülke kadar göçmenlerin de dil konusundaki "karşılıklı" sorumlulukları bütüncül bir anlayışla değerlendirilmelidir. Bu bağlamda örneğin Almanya'da genç yetişkinler, annebabalar, kadınlara yönelik dil eğitimi açısından çeşitli uyum kursları verilmekte; göçmenler için Almanca Testi ve Almanya'da Yaşamak Testi yapılmakta ve B1 düzeyinde sonuç almaları beklenmektedir (Köse ve Özsoy, 2019). Hollanda ise söz konusu sınavları göçmen bireyler ülkeye girmeden önce yapmaktadır. İngiltere ise Almanya ve Hollanda'nın aksine kültür temelli değil daha vatandaşlık bilgisi temelinde sınavlar gerçekleştirmektedir (Synder, 2006). Dolayısıyla aile bireylerinin kültürel uyum ve aidiyet eğitiminin, çocukların ülkedeki eğitim kurumlarına ilişkin aidiyet ve uyumunu da arttıracağı düşünüldügünnde ailelerinde eğitim süreçlerine dâhil edilmesi önem kazanmaktadır. Bu süreçteki karşılıklı anlayış, uyum ve aidiyet konusundaki kurumsal sorumlulukların göçmenlerin bireysel sorumlulukları tarafından desteklenmesini de sağlayacaktır.

Ailelerin çocuklarının eğitim hayatı ile yakından ilgilenebilmesi ve destek olabilmesi için okul aile işbirliği ilişkileri güçlendirilmelidir. Sarıtaş, Şahin ve Çatalbaş (2016) tarafindan gerçekleştirilen çalışmada öğretmenlerin ve idarecilerin göçmen velilerle iletişim, ilgisizlik, ödev takibini yapmama, ders materyali sağlayamama gibi bazı sorunlar yaşadığı görülmektedir. Yalnızca "okul kapısı ebeveynliği” değil, anne-babaların sürece dâhil olabildiği okul ortamlarının oluşturulması önem taşımaktadır. Bununla için okul yönetimi ve öğretmenlerin de güdüleyici bir rol benimsemesi gerekmektedir (SETA ve Theirworld,2017). Okul dışı aktiviteler, kermesler, sergiler vb. etkinlikler gerçekleştirilerek özellikle annelerin okul ile etkileşimi artırılmalıdır.

Göç ile gelen çocuklara eğitim verilirken, göçmen çocuklar ile beraber eğitim alan yerli çocukların da bazı eğitimlerden geçmesi gerekebilir. İki ayrı grubun uyumu için yerli çocukların tavır ve davranışları burada oldukça önem taşımaktadır. Dışlayıcı ve ayrımcı bir tutum göç ile gelen çocukları uyum ve aidiyet konusunda zorlaştırıcı sürece doğru itecektir. $\mathrm{Bu}$ yüzden yerli çocuklar ve göçmen çocukların uyumu için de gerekli çalışmalar yapılmalıdir.

Göç sonrası yeni yaşanmaya başlanılan alanda, okulda ayrımcılık ya da sosyal dışlanmaya maruz kalma göçmen çocuğun ruh sağlı̆̆ını ve zihinsel süreçlerini etkileyen etmenlerden biri olarak değerlendirilmektedir (Kirmayer vd, 2011). Öğretmenlerin derslerde grupla öğretim yöntemlerine ağırlık vermesi, kuralların tüm öğrencilerle birlikte oluşturulması göçmen çocukların sosyal ilişkilerini geliştirmesine katkı sağlayacaktır. Bu amaçla derste ve ders dışı etkinliklerde gruplar oluştururken, heterojen yapıda olmasına özen gösterilmelidir.

Öğretmenler göç ve göçmenler ile ilgili bilgi sahibi olmalıdır. Öğretmenin tutumu ile göçmen çocuk okula daha da yakınlaşabilmekte ya da uzaklaşabilmektedir. Başat faktör olarak öne çıkan öğretmen, göçmen çocukların yabancı bir ülkeye ve yabancı bir kültüre uyum sağlamaya çalıştığını unutmamalı buna yönelik davranmalıdır.

\section{Kaynakça}


Akdoğan, A. A., \& Köksal, O. (2014). Aidiyet algısının örgütsel vatandaşlık davranış1 üzerindeki etkisinde yöneticiye güvenin arac1lık rolü. Atatürk Üniversitesi Sosyal Bilimler Enstitüsü Dergisi, 18(1), 25-43.

Akıncı, B., Nergiz, A., \& Gedik, E. (2015). Uyum süreci üzerine bir değerlendirme: Göç ve toplumsal kabul. Göç Araştırmaları Dergisi, 1(2), 58-83.

Alptekin, D. (2011). Toplumsal aidiyet ve gençlik: Üniversite gençliğinin aidiyeti üzerine sosyolojik bir araştırma (Doktora Tezi). Selçuk Üniversitesi Sosyal Bilimler Enstitüsü.

Aşkın, M. (2007). Kimlik ve giydirilmiş kimlikler. Atatürk Üniversitesi Sosyal Bilimler Enstitüsü Dergisi, 10(2), 213-220.

Avc1, M. (2006). Ergenlikte toplumsal uyum sorunlar1. Atatürk Üniversitesi Sosyal Bilimler Enstitüsü Dergisi, 7(1), 39-63.

Baumeister, R. F., \& Leary, M. R. (1995). The need to belong: desire for interpersonal attachments as a fundamental human motivation. Psychological bulletin, 117(3), 497.

Bezirgan, M., \& Koç, F. (2014). Yerel mutfakların destinasyona yönelik aidiyet oluşumuna etkisi: Cunda Adası örneği. Journal of International Social Research, 7(34), 917-928.

Bilgin, N. (2007). Kimlik inşası. İzmir: Aşina Kitaplar

Bozkurt, T. (2006). Poşalar örneğinde etnisite ve toplumsal cinsiyet ilişkisi. Ç. Cehhan Suvari (Ed.), Artakalanlar, Anadolu'dan Etnik Manzaralar içinde (s. 283-355). İstanbul: E Yayınları.

Brocato, E. D. (2006). Place attachment: an investigation of environments and outcomes in service context (Unpublished Doctoral Thesis). The University of Texas at Arlington.Texas.

Çağırkan, B. (2016). Göç, hibrit kimlik ve aidiyet: yeni toplumlar, Yeni Kimlikler.Insan ve Toplum Bilimleri Araştırmaları Dergisi, 5(8),2613-2623.

Çakırer-Özservet, Y. (2014). 1990’lardan bu yana çocuk dostu bir şehir: Fano. Marmara Belediyeler: Marmara Bölgesi Yerel Belediyeler

Çakırer Özservet, Y. (2016). Uluslararası göç, yerel yönetimler ve toplumsal uyum. TBB İller ve Belediyeler Dergisi, 813, 48-55.

Dalbay, R. S. (2018). "Kimlik" ve "Toplumsal Kimlik" kavramı. Süleyman Demirel Üniversitesi Sosyal Bilimler Enstitüsü Dergisi, 31, 161-176.

Deringöz, T. (2017). Kentsel dönüşümün kentsel aidiyet duygusu üzerindeki etkisi: Kırşehir ili örneği (Yüksek Lisans Tezi). Aksaray Üniversitesi, Sosyal Bilimler Enstitüsü. 
Erdem, C.(2017). Sınıfında mülteci öğrenci bulunan sınıf öğretmenlerinin yaşadıkları öğretimsel sorunlar ve çözüme dair önerileri. Medeniyet Eğitim Araştırmaları Dergisi. $1(1), 26-42$.

Erdoğan, M. M. (2014). Türkiye'deki Suriyeliler: Toplumsal kabul ve uyum araştırmast, Hacettepe Üniversitesi, göç ve siyaset araştırmaları merkezi. HUGO Yayınları.

Ergün, D. (2000), Kimlikler klskacında ulusal kişilik. Ankara: İmge Kitabevi Yayınları.

Gencer, T. E. (2017). Göç ve eğitim ilişkisi üzerine bir değerlendirme: Suriyeli çocukların eğitim gereksinimi ve okullaşma süreçlerinde karşılaştıkları güçlükler. Journal of International Social Research, 10(54), 838-851.

Gençöz, F. (1998). Uyum psikolojisi. Kriz Dergisi, 6(2), 1-7.

Hazan, C. \& Shaver, P. (1994). Attachment as an organizational framework for research on close relationships. Psychological Inquiry, 5, 1-22.

Kadıoğlu, Z. K. (2013). Kitle iletişim araçlarının şekillendirdiği sosyal kimlikler ve aidiyet duygusu ekseninde tüketici davranışları. İstanbul Üniversitesi İletişim Fakültesi Dergisi Istanbul University Faculty of Communication Journal, (45), 101-114.

Kaştan, Y. (2015). Türkiye'de göç yaşamış çocukların eğitim sürecinde karşılaşılan problemler. Uluslararası Sosyal ve Eğitim Bilimleri Dergisi, 2(4), 216-229.

Kılıçoğlu, G. (2014). İngiltere'deki öğretmenlerin çokkültürlü ögrretim yeterlikleri ile türk ögrencilerin kültürleşme tercihlerinin okula aidiyet duygusu ve akademik başarılyla ilgisi..http://openaccess.ogu.edu.tr:8080/ adresinden 18.06.2018 tarihinde erişilmiştir.

Kirmayer, L. J.,Narasiah, L., Munoz, M., Rashid, M., Ryder, A. \& diğerleri. (2011). Common mental health problems in immigrants and refugees: general approach in primary care. Canadian Guidelines for Immigrant Health. http://psychiatry.utoronto.ca/ adresinden 21.06.2018 tarihinde erişilmiştir.

Köse, D. \& Özsoy, D. (2019). Göçmenlere Dil Öğretimi Almanya Türkiye Örneği. Uluslararası Yabancı Dil Olarak Türkçe Öğretimi Dergisi, 2(1), 112-125.

Murphy-Lejeune, E. (2001). Student mobility \& narrative in Europe: The New Strangers, Routledge, Florence, USA.

Özbek, Ç., \& Şahan, İ. E. (2016). Yabancı yerleşimcilerin toplumsal aidiyetlerinin yerelde kurulma pratikleri: The post gazetesi örneği. Fen Edebiyat Fakültesi Sosyal Bilimler Dergisi, 38, 159-182.

Özdil, M. (2017). Kolektif ve bireysel kimlikler bağlamında sosyal bütünleşme. Süleyman Demirel Üniversitesi Sosyal Bilimler Enstisüsü Dergisi, 28, 383-400.

Özdil, M. (2017). Kolektif ve bireysel kimlikler bağlamında sosyal bütünleşme. Journal of Suleyman Demirel University Institute of Social Sciences, 28(3). 
Sarıtaş, E., Şahin, Ü., \& Çatalbaş, G. (2016). İlkokullarda yabancı uyruklu öğrencilerle karşılaşılan sorunlar. Pamukkale Üniversitesi Sosyal Bilimler Enstitüsü Dergisi, (Ek1),s. 208-229.

SETA \& Theirworld (2017). Engelleri aşmak: Türkiye'de Suriyeli çocukları okullaştırmak. https://setav.org/ adresinden 21.06.2018 tarihinde erişilmiştir.

Snyder, L. D. (2006). The new "integration" tests and materials in the netherlands, germany, baden-wurttemberg, and the united kingdom: the muslim other and the change from multiculturalism to assimilation, (Master Thesis), Bosphorus University.

Şeker, B. D. (2015). Göç ve uyum süreci: Sosyal psikolojik bir değerlendirme. Göç ve Uyum içinde (s. 9-21). Transnational Press London.

Şirin, A. N. (2012). 1989 göçü ve sonrası ile ilgili Türkiye"ede yapılan sosyolojik araştırmalarla ilgili bir değerlendirme. 89 göçü: Bulgaristan'da 198489 azınlık politikaları ve Türkiye’ye zorunlu göç içinde (s. 397-422). İstanbul: Yıldız Teknik Üniversitesi.

TBMM İnsan Haklarını İnceleme Komisyonu Mülteci Hakları Alt Komisyonu Göç ve Uyum Raporu (2018). https://www.tbmm.gov.tr/ adresinden 18.06.2018 tarihinde erişilmiştir.

Tellefsen, T. \& Thomas, G. P. (2005), The antecedents and consequences of organizational and personal commitment in business service relationships, Industrial Marketing Management, 34, 23-37.

Uzun, E.M. \& Bütün, E. (2016). Okul öncesi eğitim kurumlarındaki Suriyeli sığınmacı çocukların karşılaştıkları sorunlar hakkında öğretmen görüşleri. Uluslararası Erken Çocukluk Eğitimi Çalışmaları Dergisi, 1(1), s.72-83.

Weiss, R. S. (1988). Loss and Recovery. Journal of Social Issues, 44, 37-52.

Yıldız, S. (2007). Kimlik ve ulusal kimlik kavramlarının toplumsal niteliği. Milli Folklor, 74, 9-16.

\section{Extended Abstract}

Motivation to live together resulting from the needs of individuals to each other is one of the important issues addressed in research conducted in the field of psychology, social psychology and sociology (Alptekin, 2011: 60). In particular, the intense migration and thereby social changes and transformations in recent years have led to the reinterpretation of the concepts of harmony and belonging and opened many aspects of these concepts to discussion. In this context, belonging is defined as a basic human motivation and it is emphasized that belonging is a functional desire in the construction, development and sustainability of interpersonal relations.

The concept of belonging defines where, what and how the individual has commitment in the emotional and spatial dimension and at the same time it is influenced by emotions, beliefs, 
political orientations and character of individual. The birth of the individual starts his belonging to a family, a community, a social order and thus the concept of belonging begins to take root and it becomes both an obligation and a choice in the following processes. When it is evaluated on an individual basis, since the elements such as experience, culture, readiness, belief, point of view, space, object constitute the skeleton of the concept of belonging, a common definition or generalization regarding this concept does not seem possible. Recently, it is seen that the concepts of identity-belonging-harmony are discussed in terms of migration from the sociological perspective.

When it is dealt with especially in terms of immigrants, it can be seen that the identity dimension of the concept of belonging comes to the forefront and identity formation is critical. "Identity involves both a differentiation between the individual and the other, and it is built on the basis of identification between himself and others" (Bilgin, 2007: 95). While migrants adapt themselves to the society to a certain extent over time, they have certain difficulties in defining their belonging and identity because the concepts of identity and belonging are not only nourished by absolute and unchanging elements from the past, but also built together with the cultural interaction in the future with a number of goals.

Harmony is the process of a balanced relationship with the self and the environment by carrying the individual characteristics of the individual (Avc1, 2006). With the concept of harmony, it is often meant to mean transition from one situation to another. There is a general consensus on Philip's definition of the concept of harmony. According to this definition, adaptation is the change of an individual's behavior in order to adapt to local customs and traditions.

In many studies and researches, harmony and belonging are mostly considered together with the concepts of "social integration" and "integration." As it is pointed out in Turkey Grand National Assembly Investigation Commission on Human Rights Refugee Rights SubCommission on Migration and Integration Report (2018), multiculturalism conceptual basis in this context such as empathy, tolerance, cohesion, participation, coexistence, assimilation, acceptance, absorption, integration , integration, adaptation are discussed ${ }^{1}$.In this process, migrants can have the opportunity to build a unique identity along with the hybridization process, unlike the assimilation process. As a result of this situation, as Çağırkan (2016) states,"American Chinese, Turkish origin German Footballer, Punkist, Arsenal Fan, etc." identity definitions can be made. The process of establishing a hybrid identity is also important in terms of self-identification "step, which is one of the most troublesome and painful processes for the immigrants who have completed the adaptation process because it creates an opportunity for individuals to create their own free zones in terms of identity.

It is seen that as a result of the rapid changes and transformations in the international arena in the recent period, the concepts of harmony and belonging are discussed together with "migration" concept in the sociological context. However, in the last century, the concept of migration can be evaluated in the light of new conceptual categories. As Özbek and Şahan (2016: 160) stated: "Climatic migrations, health migrations, elderly migrations, retirement migrations and life-style migrations that cover all of these categories make sense". 
Considering both the conceptual categorization of migration and the general classification of internal and external migration; the subject of compliance and belonging covers all individuals regardless of the reasons for migration, the integrated effects of migration in different areas, the behavior and attitudes of migrants, the responses of the settled people in the region to migrants.

Since 2011, the Syrian civil war and hardship have led immigration flows to a degree that has never been experienced before. With the open-door border policy, this drama in the border / neighboring country has shown an urgent and humanitarian attitude. These people were placed to temporary camps in the border region but the the capacity of the camping area was insufficient and conflicts in Syria continued and this resulted in migration flows into Turkey. A great many of the migrants had to settle up in different cities in Turkey (Çakırer; Özservet, 2014). According to the report of Interior Ministry Immigration Administration General Directorate on March 22, 2018, compared to the previous month, the Syrians in the number of refugees who registered their biometric data in Turkey increased by 21 thousand 59 people stated that a total of 3 million 561 thousand 707 people. Of this 1 million 931 thousand people 717's than men, and 1 million 629 thousand 990 are women (https://www.umhd.org.tr/ 2018/ 04/ turkiyedeki - suriyeli-multeci-sayisi-20-bin-artti/). Almost no country has encountered so many asylum seekers / immigrants in such a short time throughout history.

The most important problems that migrants experience in the host country are as follows: lack of knowledge of the host country language, employment, problems resulted from language or host community, housing problems, the problem of not performing religious rituals if they have a different religion with the host society, severity of negative attitudes, adaptation process to the new environment, economic difficulties and cultural differences (Çakırer Özservet, 2016: 54). In order to solve these problems, it is possible to have detailed information about the immigrants' cultures, religions, socio-economic structures and possible contributions to the host culture. Once the migrants are known for their detailed knowledge, economic, social and cultural policies can be determined. Thus, they can also contribute to the host community. 